\title{
Changes in land use and their impact on the coastal zone in northern Sinaloa (Gulf of California, Mexico)
}

\author{
P. Muñoz ${ }^{1}$, L. Menanteau ${ }^{2} \&$ D. Escobedo ${ }^{3}$ \\ ${ }^{I}$ CIIEMAD-IPN, Mexico \\ ${ }^{2}$ CNRS-Université de Nantes, France \\ ${ }^{3}$ CIIDIR-Sinaloa-IPN, Mexico
}

\begin{abstract}
Sinaloa State is the second largest producer of shrimp in Mexico, after Sonora, (in 2008 more than 35,000 tones, and 300 shrimp farms covering approximately $28000 \mathrm{ha}$ ); with most of the production being exported to the United States. Sinaloa is one of the 31 states of Mexico, located in the northwestern part of the country. The state covers an area of 57,377 square kilometers and has 2.2 million inhabitants. The coastal plain is a narrow strip of land that stretches along the length of the state; this is located between the ocean and the mountain range "Sierra Madre Occidental", which dominates the eastern part of the state. Sinaloa is traversed by many rivers, which carve broad valleys. The largest of these rivers are the "Culiacan", "El Fuerte" and "Sinaloa". The main productive activities are agriculture, fishing, livestock breeding, shrimp aquaculture, commerce and industry. Apart from being the second largest shrimp producer in the country, Sinaloa is the most prominent state in terms of agriculture and has the second largest fishing fleet. As a result of these economic activities, the northern region of the State has experienced major changes in land use, mainly in the river deltas, being mostly devoted to aquaculture and agriculture. In terms of aquaculture, the river delta of "El Fuerte", one of the three largest rivers in the State, has undergone significant changes with a vast increase in surface for the cultivation of shrimp, from 364 ha in 1990 to 7,194 ha for year 2008 (ISA, 2007), with the consequent impact on the coastal lagoons of the region, including mangroves (LANDSAT and SPOT images).In the Topolobampo lagoon system there are evident impacts on the quality of water from adjacent coastal ecosystems due to the concentration of two nutrients: nitrates and phosphates,
\end{abstract}


from the aquaculture activities in 2007 (11 farms) with values of 2,98 tons/year of total phosphorus and 30,02 tons/year of total nitrogen in its different forms (DIN, SRP, PO4), contributing significantly to the process of coastal eutrophication.

Keywords: land use, aquaculture, mangrove forests, coastal eutrophication.

\section{Introduction}

Globally diverse human activities impact the environment and ecosystems more quickly than the population is aware of in its effects. Aquatic ecosystems include extremely complex environments and for decades have been intensively used. In particular, the impact on the subject of this study, where ecosystems have been located mainly on coastal water bodies, and where much of the exploitable marine resources are concentrated.

On the Mexican Coast, coastal systems support various and significant fisheries, are reservoirs of biological diversity and provide unparalleled recreational opportunities. Due to such characteristics and to the growing development of human settlements in these environments, the demand on marine resources increased considerably which has led to the deterioration of the ecosystems with the subsequent impact on productive activities by the disappearance of habitats, creating an environmental problem, and increasingly complex economic and social problems.

Sinaloa State is located in Northwest Mexico, limited by the States of Sonora, Chihuahua, Durango, Nayarit and California Gulf. Territorial surface is of $58,092 \mathrm{~km}$, including $656 \mathrm{~km}$ of coast with abundant estuarine systems. Agriculture, livestock and aquaculture are the main economic activities in the State, and on a smaller scale mining ( $\mathrm{Ag}, \mathrm{Au}, \mathrm{Zn}$ and $\mathrm{Cu}$ ), which is one of the largest producers in the Northwest region of the country. Agriculture activities are favored by the plentiful irrigation (Figure 1), only in the northern portion of the State are located the basins of the rivers El Fuerte and Sinaloa districts of irrigation 075 strong River 076 Valley of the Carrizo and 063 River Sinaloa, supplying an area of approximately 600,000 hectares. For this reason the use of various types of fertilizers and pesticides are undoubtedly one of the main concerns about the possible impact on ecosystems (freshwater and marine), and the quality of the products (agricultural, aquaculture and fisheries) which are intended for human consumption. Another problem presented is wastewater discharge in the bed of the rivers, through drains, creeks, lagoons or bays as result of inefficiency or lack of treatment plants in some of major cities such as Los Mochis, Guasave and Guamúchil. This situation creates a serious problem for the coastal north of the region, if it is considered that there are about $700 \mathrm{~km}^{2}$ systems lagoon where they develop different species of commercial shrimp, oyster, clam, crab, axe callus and a great diversity of species of scale, all serving the ecosystems. 


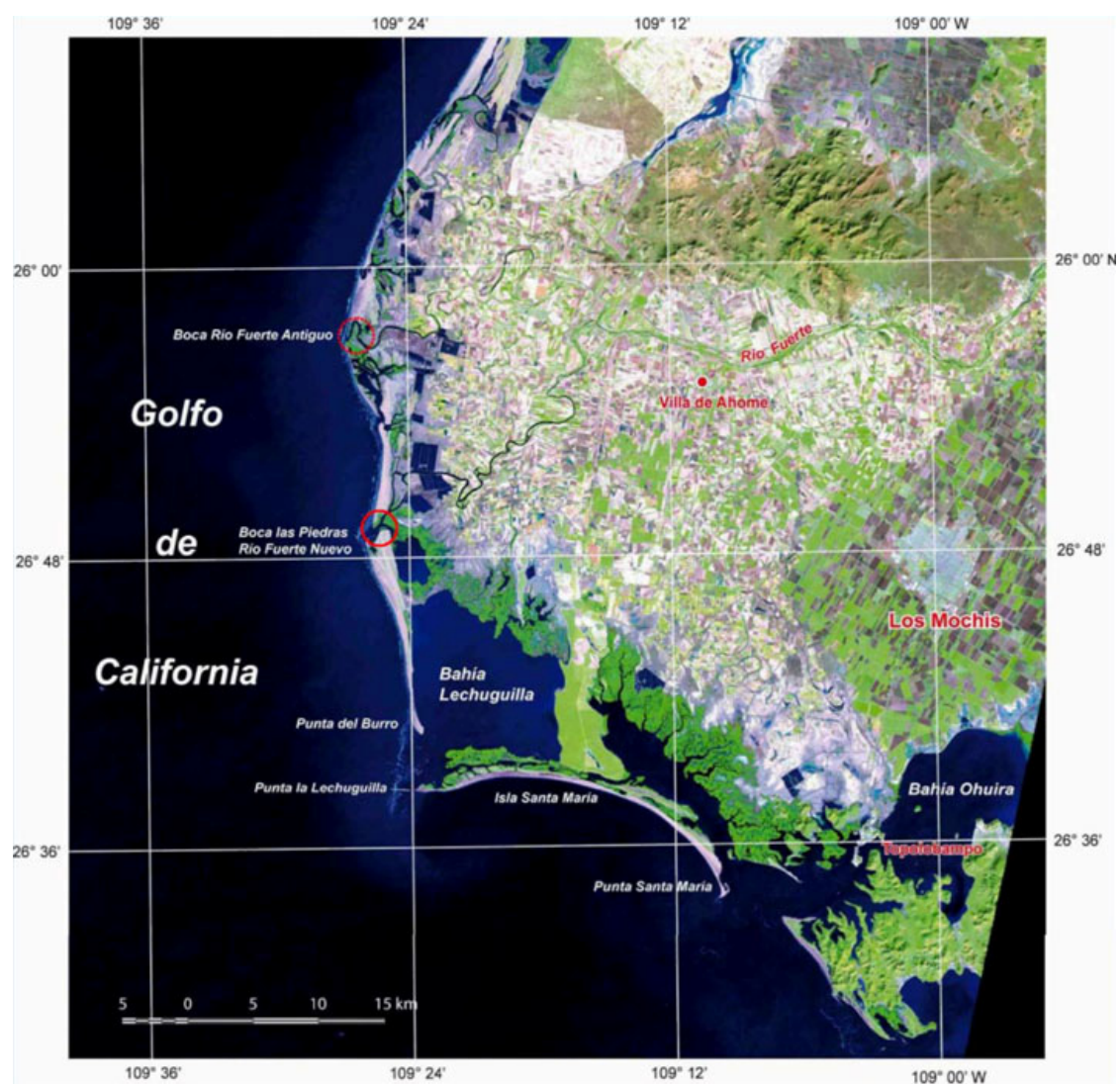

Figure 1: Delta of river "El Fuerte".

At least two of the most important activities in the region, agriculture and aquaculture occur in areas where the change in land use has been constantly growing.

\section{Change in land use}

Agricultural expansion is a special case of the frequent changes brought about by human land use, or the type of utilization of terrestrial ecosystems. Today, such a change is an important part of the so-called global change, along with climatic alterations and changes in atmospheric composition. Its consequences exceed local or regional level (Carabias [1]). Agricultural expansion influences on climate cycles of water, carbon and nitrogen in the biosphere, the emission of gases causing the greenhouse effect and biodiversity. At the same time, to an increasing demand for food and fiber, the increase in agricultural land appears as an inevitable process Elvira [3]. Social and environmental consequences also 
underline the importance of carefully planning the expansion of the areas intended for cultivation worldwide, as well as those aimed at aquaculture in growing expansion. Mexico land suffers from the same threats as the rest of the soils of the world. Our losses in this category are: by water erosion, $56 \%$; by wind erosion, 28\%; by chemical degradation 12 per cent and physical degradation 4 per cent. Human activities that cause soil degradation in our country - the same in the world - are: deforestation, with 29 per cent of the total damage; inadequate agricultural practices with $28 \%$; overgrazing with $35 \% \mathrm{M}$; extraction of firewood, with $7 \%$, and industry and urbanization, with $1 \%$. The causes of deforestation in Mexico include: agricultural cuttings with $82 \%$ of the total; damage illegal logging with $8 \%$ wildfires with $3 \%$; pests and diseases with $3 \%$; authorized changes with $2 \%$, and others, with $2 \%$. Change of land use in our country is regarded as the second largest source of $\mathrm{CO}_{2}$ generation (Paruelo [3]).

In the State of Sinaloa agriculture is significant, however this study analyses primarily land occupation by another important activity of the State as it is the case of the shrimp culture, Sinaloa State is the second largest producer of shrimp in Mexico, after Sonora (in 2008 more than 35000 tones, 300 shrimp farms, covering approximately 28000 ha; Figures 2 and 3 ).

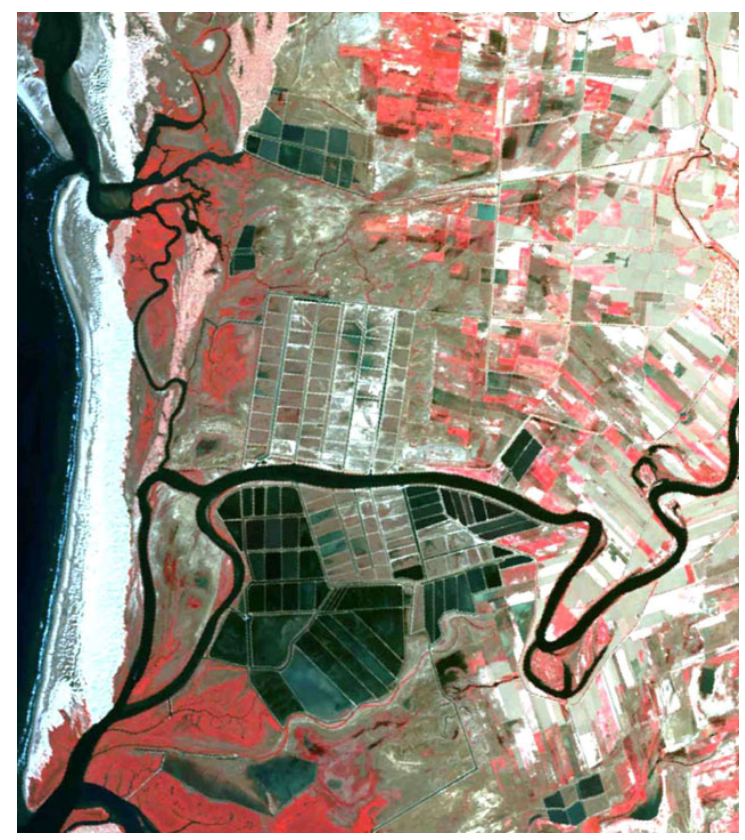

Figure 2: Shrimp farms, in the ancient delta of river "El Fuerte". 


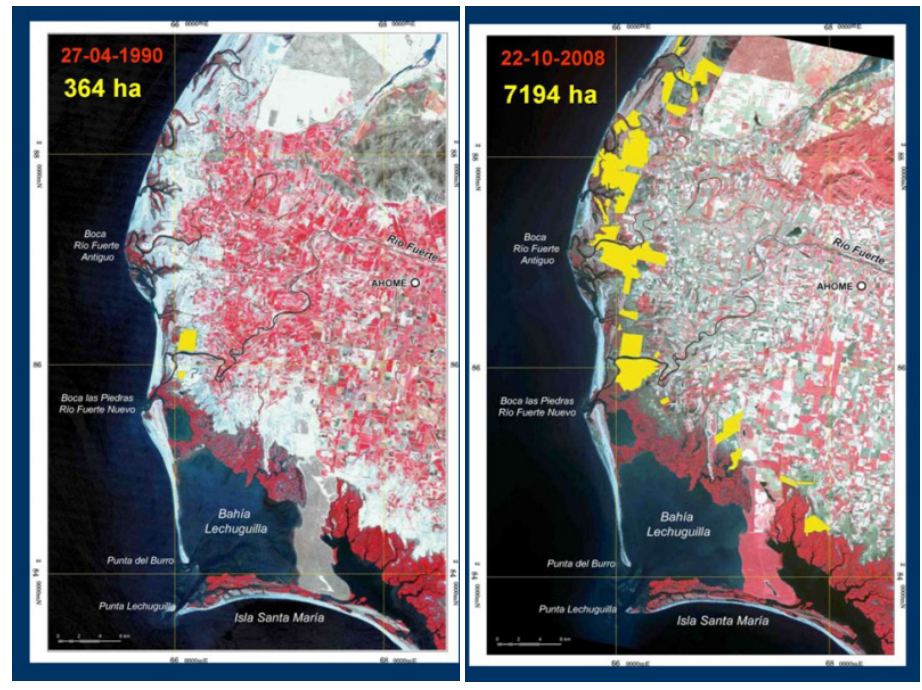

Figure 3: Use land change by development of shrimp farms (1990-2008) in northern Sinaloa, Mexico.

\subsection{Aquaculture activity in Sinaloa}

On a global scale, aquaculture is one of the food cultures where production is very fast with a 10\% annual growth (Biao and Zhuhong [4]). In Latin America, prawn production passed 172 million tonnes in 1984, 921 million tonnes in 1994 Tobey et al. [5]. In Mexico, the production of prawns and crab almost increased four-fold from 13 million tonnes in 1996 to 47 million tonnes in 2001 respectively. In the high seas alone the prawns captured was 38 million tonnes during 2001 (Flores-Nava and Euán-Avila [6]).

However, the intensity and increase in prawn production activities has caused considerable alterations in the ecosystems. The mangroves ecosystem very close to the coastal region is the main area which is affected and nearly $5 \%$ of these areas were affected during the last decade (Phillips and Beveridge [7]). It is very well established that nearly $25 \%$ of the mangroves are destroyed in the world due to this activity (Clay [8]); also they modify the hydrodynamic patterns and the quality of water of many coastal ecosystems (Tobey et al [5]; Páez-Osuna [9]; Páez-Osuna [10]; Flores-Nava and Euán-Avila [6]). The activity is also responsible for the introduction of exotic pathogens microorganisms with several consequences in many countries NRC [11].

In the Sinaloa State, the prawn cultivation started experimentally during 1971 in a big manner in the Lagoon system of Caimanero. It attained great significance and they were commercialized during 1983, after the increase in production from the regions of River Fuerte in the Northern part of Sinaloa State (Lyle and Romero [12]). The prawn culture activity was affected seriously during 1994 to 1997 due to a virus which is well known as "Yellow Head" and "White Spot". The diseases decreased the production level by nearly half a 
million tonne/ $\mathrm{Ha}^{-1}$ on average in 1996. Actually, the overall average is between 0.8 to 1.2 tonnes per hectare for non intensive culture (Anonymous [13]; Lyle and Romero [14]).

\section{Methodology}

The intensity of aquaculture development in the northern part of Sinaloa State has increased the effluent input into the coastal region and at the present time there is no direct effluent treatment way to reduce their effect in the receiving aquatic regions. In the lagoon system of Topobampo we found 10 shrimp farms covering a total area of 1,257 has CONANP [15]. However, the contribution of effluents due to the aquaculture activity was never monitored, for that reason a sampling was done every fifteen days in the area during March to September 2007 , in the entry points (canal region) and in outlet points (drainage points), as it is in the reservoirs. We used for each station a multi-parameter probe (Horiba $\mathrm{U}-10)$ to register the temperature, salinity, $\mathrm{pH}$ and dissolved oxygen. Samples were also taken to identify nutrients $\left(\mathrm{NH}_{4}{ }^{+}\right)$, dissolved inorganic phosphate (DIP), silicate (Si), total nitrogen (TN) and total phosphorous (TP), total suspended solids (TSS), particulate organic matter (POM) and chlorophyll (Cl) in all the regions. For the last years in the study area the white spot syndrome virus (WSSV) has reoccurred, for that reason was not possible to get environmental data to avoid the use of probes that could produce a contagion effect between different farms.

The samples collected every fifteen days were filtered using a GF/F glass filter (pore size $0.7 \mu \mathrm{m}$ ) for the analysis of inorganic dissolved nutrients $\left(\mathrm{NO}_{3}\right.$, $\mathrm{NO}_{2}, \mathrm{NH}_{4}{ }^{+}, \mathrm{PO}_{4}{ }^{3-}, \mathrm{SiO}_{3}{ }^{2-}$ ). The analysis of ammonia was done instantly, whereas a part of the samples were filtered for subsequent analysis. The preserved filtered samples were used for the analysis of total nitrogen and total phosphorus. The samples were also analyzed for chloride and the calculation was done based on the equations of Jeffrey and Humphrey.

The determination of inorganic nutrients was done using spectrophotometer following the method of Strickland and Parsons (1972). The analysis of total nitrogen (TN) and total phosphorus (TP) was done using the method of Valderrama [16] and Strickland and Parsons [17].The determination of TSS and POM was done on the glass filtered samples using Whatman GF/C, $1.2 \mu \mathrm{m}$, which was dried at $550^{\circ} \mathrm{C}$. Likewise, the filters were dried sufficiently to measure TSS and POM using total ash technique as described in APHA [18]. The calculated activity of nutrients was done using a multi monitoring equipment which was based one day before harvesting to identify the contribution by aquaculture activities. Moreover, the infection due to virus, "White Spot" was also observed in many areas. The average concentration of DIN, TN, DIP and TP $\left(\mathrm{Kg} \mathrm{Ha}^{-1}\right)$ for one cycle is a simple multiplication for the extensive activity of $\mathrm{N}$ and $\mathrm{P}$ contribution to the ecosystem, in tonnes per cycle $\mathrm{e}^{-1}$, and per year this can be multiplied by a factor of 1.68 depending on the number of cycles during the activity (Lyle-Fritch and Romero [14]). 
In other terms, the differences in determination of each site vs each entry points often vary from time to time. Hence, the ANOVA variance analysis or the Kruskall-Wallis non-parametric analysis is used when the analyzed variables did not show a normal distribution (Zar [19]).

\section{Results}

The calculated contributions of nutrients due to aqua culture activity on an overall average were 0.88 and $0.54 \mathrm{Kg} \mathrm{Ha}^{-1}$ per year of dissolved inorganic nitrogen and dissolved inorganic phosphorus (Table 1). Likewise, it was 25.2

Table 1: $\quad$ Values of nutrients concentrations, SST y MOP, in the shrimp culture pools located in the north of Sinaloa (2007-2009).

\begin{tabular}{|c|l|c|}
\hline Variables & Concentration \\
\hline & Max & 0.29 \\
\hline NID & Min & 0.01 \\
\hline & Average & 0.05 \\
\hline & Max & 0.65 \\
\hline PID & Min & 0.0005 \\
\hline & Average & 0.03 \\
\hline & Max & 2.92 \\
\hline NT & Min & 0.24 \\
\hline & Average & 1.50 \\
\hline & Max & 0.65 \\
\hline FT & Min & 0.02 \\
\hline & Average & 0.15 \\
\hline & Max & 348.00 \\
\hline SST & Min & 8.67 \\
\hline & Average & 104.72 \\
\hline & Max & 73.64 \\
\hline MOP & Min & 3.72 \\
\hline & Average & 24.93 \\
\hline & & \\
\hline
\end{tabular}


and $2.49 \mathrm{Kg} \mathrm{Ha}^{-1}$ per year of total nitrogen and total phosphorus respectively. Miranda and Voltolina [20] calculated an annual average of $122 \mathrm{Kg} \mathrm{Ha}^{-1}$ of total nitrogen and $14 \mathrm{Kg} \mathrm{Ha}^{-1}$ per year of total phosphorous from the aqua culture region. These estimations were generated from the present study. The contribution from the aquaculture activity measured for other regions around the World by Lemonnier and Faninoz [21] and Jackson and Preston [22] reported a total nitrogen values between 55.1 to $121.2 \mathrm{Kg} \mathrm{Ha}-1$ per year. The big difference between contributions from aqua culture is attributed to other reasons, where sampling technique also plays a role (Páez-Osuna and Guerrero-Galván [23]), but the main problem is the lack of analysis of the entry and outlet points, particularly for the different

forms of dissolved nitrogen that can vary, even among reservoirs from the same farm. On the other side in our work we encountered very low values which are attributed due to the low contribution of nutrients. These are mainly due to the low contribution of the nutrients measured in the water column after the aquaculture cultivation. The low quantity of organic material and particles in the sediments with nutrients also acts as a natural medium for the nutrient transport. Additionally, most of the work on other sites was based on blank calculation of masses with no direct measurement in the field, which could underestimate the contributions. The data from the present study are almost similar to the other authors, for that reason we conclude that is necessary to homogenize methodologies for the calculation of farms contribution; only in that way the results can be compared.

However, when the total nutrient values measured in the reservoirs were very high and the inorganic nutrients relatively low, inclusive lower than average contribution reported for the adjacent lagoon system (Escobedo Urías and Hernández-Real [24]; Magaña-Alvarez, [25]; Poot-Delgado [26]). This situation wrongly suggests that the reservoirs act as a nutrient filters in many cases and thus effluent treatment is not necessary.

As we can observe, for the present study the major part of nitrogen and phosphorous generated in the reservoirs is often present in organic form (dissolved or particulate) which is not measured routinely during the cultivation cycle. According with this concept the result is a bad practice related to the reservoir fertilization and a lack of treatment for the waters going out directly for the system to the coastal lagoons, many of these bodies with a strong environmental impact.

\section{References}

[1] Facultad de Ciencias, UNAM, Cambio de uso de suelo y servicios ambientales en el contexto de cambio climático; Carabias, Julia: México. Online:http://www.cambioclimaticoyseguridadnacional.org/documentos/Jul ia\%20Carabias\%20Cambio\%20de\%20Uso\%20de\%20Suelo.pdf

[2] Procuraduría Federal de Protección al Ambiente, El cambio de uso de suelo y sus repercusiones en la atmósfera, Elvira-Quesada, Juan Rafael: México. Online: http://www2.ine.gob.mx/publicaciones/libros/508/cambiouso.pdf 
[3] Facultad de Agronomía. UBA, Expansión agrícola y cambios en el uso de suelo. Paruelo, J.M., Argentina, Online http://www.cienciahoy.org.ar /ln/hoy87/expansion.htm

[4] Biao, X. \&Zhuhong, D. Impact of the intensive shrimp farming on the water quality of the adjacent coastal creeks from Eastern China. Marine Pollution Bulletin, 48(5-6), pp. 543-553. 2004

[5] Tobey, J., Clay, J. \&Vergne. P. The economic, environmental and social impacts of shrimp farming in Latin America. Coastal Management Report \#2202, Coastal Resource Center, University of Rhode Island: USA. 1998.

[6] Flores-Nava, A. \& Euán-Avila, J. La Acuacultura en el marco del Manejo Integral de la Zona Costera: Reflexiones Generales, El manejo costero en México, ed. E.G. Rivera, EPOMEX-CETYS-Universidad de Quintana RooSEMARNAT: México, pp. 551-560, 2006.

[7] Phillips, M.C. \&Beveridge, M. Shrimp culture and the environment: lessons from the world's most rapidly expanding warm water aquaculture sector. Environment and Aquaculture in Developing Countries, Ed. M.C. Pullin, ICLARM: Bangkok, pp. 171-197, 1993.

[8] Clay, J. Markets Potential for Readdressing the Environmental Impact of Wild Captured and Pond Produced Shrimp, Manuscript. World Wildlife Fund: Washington, 188 p. 1996.

[9] Páez-Osuna, F. Camaronicultura y medio ambiente, ICMYL-UNAM, Colegio de Sinaloa: México, 451 p, 2001

[10] Páez-Osuna, F. Retos y perspectivas de la camaronicultura en la zona costera. Revista Latinoamericana de Recursos Naturales, 1, pp. 21-31, 2005

[11] NRC (National Research Council). Marine Aquaculture: Opportunities for Growth, Nat. Acad. Press: Washington, p. 118, 1992.

[12] Lyle, L. \& Romero, E. Desarrollo y características de las granjas camaronícolas en Sinaloa. Camaronicultura y medio ambiente, ed. F. PáezOsuna, Instituto de Ciencia del Mar y Limnología. Programa Universitario de Alimentos, El Colegio de Sinaloa: México, Pp. 351-372.

[13] Anonymous. Salud, ambiente y acuicultura en la costa Pacífica de México, PACRC/UHH, UAS, Ecocostas, A.C./Ecuador, CIAD, Centro de Recursos Costeros / Universidad de Rhode Island, Conservation International México A. C., CESASIN: México, 149 p, 2006.

[14] Lyle-Fritch, L. P. \& Romero-Beltrán, E. A survey on use of the chemical and biological products for shrimp farming in Sinaloa (NW Mexico). Aquacultural Engineering, 35(3), pp. 135-146. 2006.

[15] CONANP. Sistema Lagunar San Ignacio-Navachiste-Macapule. Ficha Informativa de los Humedales de Ramsar (FIR), 24 p. 2007.

[16] Valderrama, J. C. The simultaneous analysis of total nitrogen and total phosphorus in natural waters. Marine Chemistry 10(2), pp. 109-122. 1981.

[17] Strickland, J. D. \& Parsons. A practical handbook of the sea-water analysis. J. Fisheries Research Board of Canada. Bull: Ottawa, 167 p. 1972.

[18] APHA. Standard methods for the examination of water and wastewater. 17 Edition. Washington, D.C., 1989. Folio variado. 
[19] Zar, J.H. Biostatistical analysis. 2nd ed., Prentice-Hall: New York, 718 pp, 1984.

[20] Miranda, A. \&Voltolina, D. Budget and discharges of nutrients to the Gulf of California of a semi-intensive shrimp farm (NW Mexico). Hidrobiológica, 19(1), pp. 43-48, 2009.

[21] Lemonnier, H. \&Faninoz, S. Effect of water exchange on effluent and sediment characteristics and on partial nitrogen budget in semi-intensive shrimp ponds in New Caledonia. Aquaculture research, 37(9), pp. 938-948, 2006.

[22] Jackson, C. \& Preston, N. Intake and discharge nutrient loads at three intensive shrimp farms. Aquaculture research, 35( ), pp. 1053-1061, 2004.

[23] Páez-Osuna, F. \& Guerrero-Galván, S. R., et al. Fluxes and mass balances of nutrients in a semi-intensive shrimp farm in north-western Mexico. Marine Pollution Bulletin 34(5), pp. 290-297, 1997.

[24] Escobedo-Urías, D. \& Hernández-Real, M. T. et al. Calidad bacteriológica del Sistema Lagunar de San Ignacio Navachiste, Sinaloa. Ciencia y Mar, III (9), pp. 17-27, 1999.

[25] Magaña-Álvarez, M. Distribución de nutrientes y su efecto en el nivel trófico de la laguna Macapule, Sinaloa. Tesis de Maestría. IPN-CIIDIR Sinaloa: México, 115 p. 2004.

[26] Poot-Delgado, C. Estructura de la comunidad fitoplanctónica con énfasis en las especies tóxicas y/o nocivas de la laguna de Macapule, Sinaloa, tesis de Maestría, IPN-CICIMAR: La Paz, B.C.S., México, 142 p. 2006. 